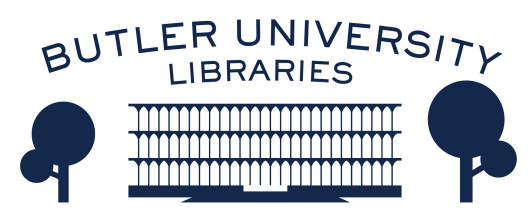

Journal of Hindu-Christian Studies

Volume 9

Article 7

January 1996

\title{
The Role of Hindu Scripture in Salvation
}

William C. Allen

Bibhuti S. Yadav

Follow this and additional works at: https://digitalcommons.butler.edu/jhcs

Part of the Religion Commons

\section{Recommended Citation}

Allen, William C. and Yadav, Bibhuti S. (1996) "The Role of Hindu Scripture in Salvation," Journal of HinduChristian Studies: Vol. 9, Article 7.

Available at: https://doi.org/10.7825/2164-6279.1129

The Journal of Hindu-Christian Studies is a publication of the Society for Hindu-Christian Studies. The digital version is made available by Digital Commons @ Butler University. For questions about the Journal or the Society, please contact cbauman@butler.edu. For more information about Digital Commons @ Butler University, please contact digitalscholarship@butler.edu. 


\title{
The Role of Hindu Scripture in Salvation
}

\author{
William C. Allen \& Bibhuti S. Yadav \\ Temple University
}

IN THIS PAPER we reflect on the role of scripture in salvation in Hinduism and Christianity. We all know that differences among various Hindu scripturologies are severe and profound. Diversities of understandings of the nature and role of scripture in salvation abound no less within the various Christian traditions. There is no Hindu consensus regarding scripture's role in salvation. Even within orthodox Hinduism the differences on this theme are fundamental. For instance, the Vedanta of Śankara reads the Vedas as descriptive of Brahman, the knowledge and realization of which constitutes moksa which Śankkara equates with meta-material, meta-social, pure being. The Mīmāmsā of Kumarila Bhatta reads the same authoritative texts as primarily injunctive, providing the impetus for those ritual and moral actions which eventuate in the attainment of svarga. Kumarila equates salvation with purusārtha, with envisioning the moral and material happiness of humanity in this life and beyond. They differ not only on the nature and role of scripture in salvation, but also on the very nature of the "salvation" to which the scriptures lead. We all know that the issue between Kumarila and Śanikara concerns this question: Is salvation a consequence of ritual and moral actions? To this question Śankkara and Kumarila have fundamentally different answers and therefore visions of scripture that are as fundamentally different. According to the Vedānta of Śankkarācārya, salvation consists in recognition of tat tvam asi - that thou art - which means recognition of human identity or self as what universally and forever is - siddhavastu - which is to say, it is not subject to human actions. Salvation lies in suspending all action, ritual and moral. To that end the scripturality śăstratatva - of the Upanisads does not lie in actions that we need to perform, but in dismissing all actions altogether, thereby recognizing our essence that transcends all actions. There is no agent and no act. Salvation lies in overcoming difference.

To this Kumarila very frankly says in the first place that there is no Brahman if by Brahman we mean an entity which always is and cannot become anything other than what it is. If there is such a thing, it is scripturally, religiously, and morally useless and so is the inquiry into such a thing. If Brahman is a thing with which we can do nothing, if we cannot know it or do anything with our knowledge of it, and if we dismiss all language to reclaim it in silence, what good is such a being? Why should human beings do anything to achieve this, much less the scriptures?

Kumarila's difference with Śankara is so fundamental that Kumarila even questions the scripturality of Śankara's whole system of thought. There is no śâstratatva. The very nature of inquiry cannot be about Brahman if Brahman is a thing in itself, but can only be about deeds that are to be performed to realize ends which scripture has predetermined, but which we are not yet in possession of. Thinking, including scriptural thinking, is not a thing in itself, nor is it a descriptive account of a thing in. itself. It is only a sādhana, an instrumental reason with which to achieve predetermined ends. The object of thinking is sädhya, a teleological ordered movement of mind. It is a case of sãdhya - that which is to be 
acquired - not siddha - not something which ontologically is and therefore autonomous of human affairs. Human existence is teleological, it seeks to be an agent of acquiring predetermined ends and being able to operate the most efficient means to those ends. Thinking is an activity of those human beings who have to be there though we have not yet arrived. Accordingly, scriptures seek to achieve salvation through commands and to that end they recommend certain actions. In that alone lies the scripturality of sāstra. No language, especially scriptural language, can transcend act-oriented concerns of ordinary human beings (vyavahāra prayogat). Kumarila says salvation is possible only through performative - not descriptive - speech. One who says the scriptures merely describe the metaphysical thereness of what we already are, is mad. They are unreflective and uncritical because they misuse the mission of language purusārta - what has to be done - not a reality which is beyond all human actions. They lack critical and common sense. Kumarila defines scripture as a body of performative speech that commands us to inquire about what is to be done and what is to be avoided, and proposes the scriptures themselves as the means to the end. ${ }^{1}$ Differences were so deep that tradition records a legendary encounter between Kumarila and Sankara on the occasion of Kumarila's self immolation. Kumarila refused to honour Sańkara's request to come off the pyre and write a commentary on his Bramasūtra, the very text in which Śñkara so aptly describes Kumarila's view of scripture as noted above.

We mention the difference to be more specific about our theme. We choose Kumarila to represent the Hindu scripture's view of salvation because he is more representative of popular and theoretical Hinduism than anyone else. Our reflection therefore focuses on the Mīmāmsā vision of scriptural means to "salvation". We want to consider four commonalities between Mīmāmsä's vision of scriptural means to salvation and that of Christianity generally, but especially those Christian traditions which maintain the plenary inspiration and infallibility of the Bible. On the face of it, what two systems could be more different than Mīmāmsā and Christianity? One is for scriptural autonomy and rejection of God; the other espouses that very autonomy in the name of God. While it would be in many respects easier to focus on the profound differences between them, the commonalities are striking, but more easily overlooked. The "scriptural word", according both to Mīmāmsā and Christianity, is: autonomous, meant to be heard, action oriented, and efficacious.

The Mīmāmsākas and Christians alike ground the authority of their respective scriptures in the autonomy of the eternal word. It is believed to be autonomous to human consciousness. Grave differences notwithstanding, Mīmāmsākas and Christians affirm the pre-existent word, whether logos or $V \bar{a} k$. We are not here interested in the philological let alone the philosophical complexities entailed in a comparison of the Greek logos with the Sanskrit Vāk. Rather we have in mind the originary source or genesis of "revealed thought". They locate the genesis of the sacred word in a transcendent realm which stands above and beyond human invention. The Bible is not the word of man writ large, nor does the Veda have any human author. The fact that Mīmāmsā altogether dispenses with God's authorship of scripture should not overshadow the more fundamental commonality shared with Christianity, namely, the word was in the beginning. It precedes and transcends human consciousness and activities. In a recent article detailing Mīmāmsā's doctrine of the authorless Veda, Bilimoria introduces his discussion with an unattributed quotation: "In the beginning was the word, and the word was with meaning". 2 Even if the commonality in phraseology proves to be no more than superficial, one cannot help but notice the resonance of these words with the 
opening verses of John's gospel: "In the beginning was the word and the word was with God and the word was God". ${ }^{3}$ The conspicuous absence of God in Mīmāmsā's doctrine of scripture need not obscure the conviction shared with Christianity. Both traditions locate the genesis of the scriptural word "in the beginning". In spite of the fact that God speaks the originary word in the Christian tradition, that word, according to the Johine witness, is co-eternal with God. Leaving aside the question of God's authorship of scripture for the time being, it appears we are on safe ground to say that Mīmāmsākas and Christians alike situate the locus of the sacred word "in the beginning". The beginning in view here does not refer to any absolute beginning. For Mīmāmsākas the Vedic word is beginningless. For Christianity, the God John identifies with the word is also beginningless. Whether primacy in Christianity is given to the word or to the God who speaks the word, the word is no less beginningless than God. It is this a priori status ascribed to the scriptural word that secures its authority in the respective faith communities. Even though the primacy of $\operatorname{God}(\mathrm{s})$ to the scriptural word is inverted by the Mīmāmsākas, both traditions exalt the autonomy of that sacred word over human convention.

We do not want to gloss over the important distinction between Mīmāminsā's adage "in the beginning was the word and the word was with meaning" with the apparent Johine parallel sentiment that "in the beginning was the word and the word was with God". It would be irresponsible and sloppy reductionism to suggest that the two expressions say the same thing. Clearly, they do not. Mīmāmsā weds the beginningless word with the meaning inherently signified by it. Christianity, on the other hand, unites the beginningless word with the God whose utterance makes it meaningful. The Mīmāmsākas were careful to avoid the circularity entailed in establishing the authority of scripture on the basis of God's role in investing words with meaning. For the Mīmāminsākas it is the scripture that speaks the gods into existence, for Christians God speaks the scriptures. Nevertheless, the originary word and its meaning is held by both traditions to be above and beyond human construction or convention. To each of these scriptural traditions the sacred text is self-evidently true and stands in need of no external criteria for validation. The Bible, no less than the Veda, speaks from a transcendent realm in which the relationship between word and meaning is beginninglessly and eternally fixed prior to entering into the mind of man. In both traditions the preexistent and transcendent speech is the agency through which the world is brought to being, which is the house of a meaningful world, and which provides the linguistic framework in which human consciousness discovers and performs the discourse about being in the world, including salvation.

The Vedic and biblical words are meant to be heard. If we regard scripture as a written word intended to be read, it is doubtful that such a designation befits either the Mīmāmsā or Christian view of scripture. Sruti denotes the very theme and method of the Veda. It is that which is heard. It is well known that the Vedic corpus was transmitted orally from generation to generation long before it was committed to writing. The same is true of the Hebrew and Greek scriptures. Even the church fathers were of the opinion that reducing the sacred word to writing profaned the exalted nature of holy utterance. When we say the scripture is meant to be heard, however, we do not have in mind the oral method of inter-generational transmission. The primacy of hearing underscores the communicative nature of the scriptural word. Mīmāmsā has often been misrepresented as exalting the sound of a word above its meaning. While it is true that the mantra is believed to be efficacious by means of its correct pronunciation, the investigation of the meaning of Vedic words and sentences is the particular domain of Mīmāmsā. This investigation is pursued in 
the oral context constituted by the teacher student relationship. The notion that the rsis are so named because they "saw" the Vedic texts is not a mixing of metaphors. They understood what they heard. Both seeing and hearing are metaphors. The sense organs are incapable of being in contact with dharma. Though dharma is an object of cognition, it is incapable of being cognized through sense-perception. To say that the scriptures are meant to be heard entails more than the audition of a magical mantric noise. The Veda is the only source for knowing dharma, knowledge of which is prerequisite to the pursuit of svarga. To hear the scripture aright entails understanding its dictates through faith in the scripture alone.

Hearing is metaphorical, but also quite literal. Transmission of the text occurs within the context of a personal sacred relationship between teacher and student. The context gives primacy to orality. While the scripture itself is a-personal, the mode through which it is communicated is highly personal. Scholars have well noted the interpsychological dimensions peculiar to oral

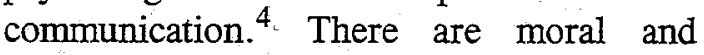
spiritual prerequisites to hearing. Scriptural transmission does not proceed indiscriminately. Only those who are morally and socially qualified are eligible to receive training in the scriptural lore. An āchärya who cannot find a worthy recipient for his textual knowledge should rather burn the text or discard it in a river than teach it to an ill-suited candidate.

It is striking to see the same primacy of orality attributed by the Greek church fathers to their own scriptural tradition. Papias (2nd century C.E.) preferred the oral communications to books. Eusebius quotes Papias as having said: "For I did not suppose that information from books would help me so much as the word of a living and surviving voice". 5 It was a Greek cultural presupposition that the writing down of profound truth was an unworthy mode of transmission. ${ }^{6}$ Written holy scriptures were not an essential foundation for early
Christianity. Ireanaeus believed that the message would have been preserved without written gospels because the oral apostolic tradition is preserved through successive church authorities to whom it was entrusted.

Hearing seems to be no less the theme and the method of the Gospels. Jesus often concluded a parable with the familiar refrain: "He who has ears to hear, let him hear what the spirit says. I teach in parables so that in hearing they do not understand. These things I have hidden from the wise and revealed them unto babes". Paul memorializes and institutionalizes the traditions's oral primacy. After all, faith comes by hearing and hearing by the word of God. ${ }^{7}$

The primacy of orality in the transmission and inherent function of the scriptural word wed Christianity and Mīmāmsā in a web of ironies. The transmission is preserved by an unbroken line of trustworthy (morally and socially qualified) disseminators and recipients. The caste system and the church stand as suspects in the same syndrome. They attribute transcendence to sacred speech and derive their authority to hear by virtue of having heard those same transcendent words. The power of mediation is in the hands of the Brahmins and of the Church fathers whose ordained role is to bring the text closer to the people. When we say that the word is meant to be heard, the hearing is metaphorical. "So that in hearing they do not understand. These things I have hidden from the wise and revealed them unto babes." There is exclusivity of privilege. Hearing is primary, but not indiscriminate. The scriptures contain the good of all and sundry, but only few have access to the hidden meaning. There are prerequisite qualifications for hearing. The Gospel is a clarion and universal call, but few are chosen. The efficacious call is consequent upon the metaphorical magic of the word that is heard.

The scriptural word is action oriented. The Veda, according to Mīmāmsā, is 
injunctive speech. It induces action. Sabdavijnana is knowledge of something to be done, derived through word. Sastra, scriptural injunction, is the means of knowing meta-sensory things (Dharma and Adharma) disclosed through verbal cognition. The Veda is the only source and means for knowing what should be done and what should not be done. The Mīmāmsākas make it their business to demonstrate that the study of the Veda is itself a dharma, a duty enjoined by the Veda itself. The act of knowing takes place when the scripture speaks. Language, according to. Mümāmsākas, is meant to be at the service of action (kriyartha), especially ritual action. Only that can be the denotation of a word which fulfils the aim of language. Language does not speak for its own sake, nor does it merely intend to refer to what is merely there and is known as such. It speaks for the sake of others, the hearers, and commands them to action. "Because Śabda is of no use for itself (nisphalatvena śabdasya) one ascertains through its competence (yogyatvāt) that it is a means toward the cognition of meaning which in its turn is an instrument for fruitful activity." 8 This in turn is the way to salvation. Action is of prime importance for the Mīmāmsākas. What leads us to act is usually an injunction or command formulated in words. But words alone do not move us to act. It is only when we grasp the meaning of the commands that action is conceived. Therefore, since understanding of meaning leads to action and because meaning - and its understanding - is transmitted through $s a b d a$, the primary purpose of $s a b d a$ is to make us act. Sabda entails all of those characteristics which provoke us to act. Meaning, especially religious meaning, imparts a world vision. It communicates coherence, order, and tranquillity, but also engages us in active concern. It translates continued and committed concerns into deeds. Meaning is conceived in the union of word, intention, and action. Meaning indicates a movement. This movement is imperative, not indicative. It does not describe; it engenders an urge to act. The meaning scripture yields is not an abstract or static notion. It is an active commitment seeking to concretize itself in the fulfilment of human hopes and dreams. Meaning attracts us to act or repels us from acting. It is never neutral. It does not describe a state of affairs in the indicative mood. It is movement motivated by an imperative.

Biblical mandates and the witness of scripture itself attest to the action-oriented nature of scripture as a means to salvation. "Be ye not hearers of the word only, but be ye doers of the word. For not by mere hearing but by the doing of the word are ye saved" (James). ${ }^{9}$ Luther refused to acknowledge James's "epistle of straw" because he could not reconcile these very words with Paul's doctrine of justification by faith alone, apart from the works. Calvin and subsequent reformation theologians upheld James's canonicity, but reconciled the doctrines of faith and works by maintaining salvation by faith alone and subordinating works to the proof of faith's authenticity. The parable of the sower and the seed is one of the rare parables whose meaning Jesus takes pains to explain. The seed is the word and the various types of ground on which the seeds fall are the different types of people who hear the words. The hearers are distinguished by the varying degrees to which the word is able to take root and flourish and bear practical results.

The word is conceived in action. Whether language speaks itself or is spoken by God is not the issue. The word is engaged in movement. The act of hearing presupposes the need to hear. Words have no intrinsic need to be heard. The need does not reside in the words that are heard, but in the one who desires to hear them.

Vedic and Biblical words are purposive and efficacious. "Those who are desirous of svarga should perform sacrifice." Even in the absence of an author of these Vedic words, their purport is clearly teleogical. 
The performance of this Vedic injunction anticipates a desired end. The authorless and therefore intentionless nature of the Veda does not preclude its purposiveness. Religious and sacramental acts presuppose intention. The Mímāmsākas locate the motivation and intentionality in the human hearer who performs the injunctions, not in the agency from which those directives are issued. We understand that in Classical India purposiveness was preceded by intentionality and intentionality preceded the agent. From Kumarila's point of view, the sáastra has no agency, no intentionality of its own and therefore is not purposive by and for itself. Purposiveness has to do with human beings who have the intentionality for salvation and this intentionality entails agency of the hearer. The hearer alone is the locus of intention. To say the Veda has no intentionality of its own is not to say it is useless. Its usefulness is the source of the Vedic word having power to make its meaning known, disclosing the otherwise inaccessible means to attain predetermined results. It reveals the purposive end towards which its adherents strive. Both the means and the soteriological end are unveiled in the injunction: "Those who are desirous of svarga should perform sacrifice". The fact that Mìmāmsa locates intentionality in the human being who desires to attain svarga does not render the Vedic word bankrupt of purposiveness. Neither is purposiveness ascribed or imputed to the text by its faith community. As we have seen, the Veda is believed to be autonomous to human consciousness and therefore does not stand in need of human beings to invest it with telos. The Vedic sentences spell out purposive mandates and guarantee prescribed means to accomplish predetermined ends. The word is therefore efficacious. When heeded and enacted, it yields predictable results. The word's inseparable relationship to its meaning constitutes its inherent purposiveness. The Mīmāmsāka does not look outside of the airtight relation between sound, word, and meaning for an independent source that invests language with teleological purpose.

Isaiah quotes the God of the Bible to say, "My word which proceeds forth out of My mouth shall not return unto me void, but shall accomplish the purpose for which it was sent". 10 The Biblical tradition has exalted God above the word, locating the teleological purpose of the word in God as its author. Without any attempt to synthesize this evidently irreconcilable rift between Christian and Mīmāminsā doctrines of scripture, we wish to highlight the mutual emphasis laid by both Christianity and Mīmanmsā on the efficacy of the sacred word. Laying aside the question of where purposiveness resides in the two disparate scriptural traditions, it appears that both locate teleological efficacy in the scriptural words themselves. The New Testament author of the letter to the Hebrews declares that, "The word of God is living and active and sharper than a two edged sword, dividing asunder both soul and spirit and able to discern the thoughts and intentions of the human heart". 11 The epistle of Peter asserts that "All scripture is inspired (literally God breathed) and efficacious for training in righteousness. ${ }^{12}$ The Psalmist declares, "The word have I hid in my heart that I might not sin against Thee". 13 Far from decontextualizing the comparative theme, this barrage of Biblical proof-texts underscores that the instrumentality and efficacy of the Biblical word is an autonomous function, of the words themselves.

Furthermore, for Mīmāmsā and Christianity the transcendent word is efficacious in producing both seen and unseen results, in this world and the next. Just as Vedic injunctions enjoin ritual and moral means to achieve both material and spiritual results, so the deuteronomic code and principles of the Kingdom entail what may equally well be called ritual and moral means, which, even if understood as ends in themselves, are nonetheless the way to fulfil predetermined material and spiritual 
interests.

We have seen that the scriptures are autonomous to human consciousness. They are meant to be heard, purposive and therefore efficacious in service of action as a means to promote human interests, visible and invisible, in this world and the next. These factors constitute the transformative nature of scripture. The efficacy of the Veda is transformation. The scripture transforms. The word is the mediative means between this world and the next, linking the world of actualities with the world of possibilities. The Vedic and Biblical word comes from above and beyond the human recipients in order to transform us from how we are to what we may become.

Our intention is not to ignore differences that are evidently too fundamental. We do not pursue the "synthetic unity" model of discourse. However, there are fundamental similarities as well and these similarities are ignored in comparative discourse as well as within Hinduism itself. Our intention is to move the Christian-Hindu discourse to other areas such as action, and not merely to reiterate the overtrodden neo-VedanticChristian highway. We understand that differences regarding scripture and salvation are too fundamental to be ignored, but the similarities are also fundamental and not seriously reflected upon by the scholarly community, especially in the comparative context of Kumarila and Christianity.

\section{Notes}

1. Brahmasütra 1:1:4, Vacaspati Mishra, Bamati, Banaras, I, pp.126-7.

2. Bilimoria, Purusottama, "On the idea of authorless revelation (apauruseya), in: Roy W. Perrett (Ed.), Indian Philosophy of Religion., Kluwer Academic Publishers, 1989.

3. John 1:1; Revised English Bible, Oxford University Press.

4. Coward, Harold, Sphota Theory of Language., Motilal Banarsidass, 1980, pp.89.

5. Eusebius, Hist. of Eccl. 3.29.4.

6. Coward, Harold, Derrida and Indian Philosophy. Albany, NY: SUNY Press, 1990, p.13.

7. Romans 10:17.

8. Kumarila Bhatta, Ślokavārtikam, pp.238-41.

9. James $1: 19: 25$.

10. Isaiah 55:10-11.

11. Hebrews $4: 12$.

12. 2 Timothy $3: 15-17$.

13. Psalm 119:11. 